Natural Hazards and Earth System Sciences (2001) 1: 203-211

(C) European Geophysical Society 2001

\title{
Large-scale slope failure and active erosion occurring in the southwest Ryukyu fore-arc area
}

\author{
T. Matsumoto ${ }^{1}$, M. Kimura ${ }^{2}$, M. Nakamura ${ }^{2}$, and T. Ono ${ }^{2}$ \\ ${ }^{1}$ JAMSTEC, 2-15 Natsushimacho, Yokosuka 237-0061, Japan \\ ${ }^{2}$ University of the Ryukyus, 1 Senbaru Nishiharacho, Okinawa 903-0129, Japan
}

Received: 30 July 2001 - Revised: 19 December 2001 - Accepted: 21 December 2001

\begin{abstract}
The southwestern Ryukyu area east of Taiwan Island is an arcuate boundary between Philippine Sea Plate and Eurasian Plate. The topographic features in the area are characterised by (1) a large-scale amphitheatre off Ishigaki Island, just on the estimated epicentre of the tsunamigenic earthquake in 1771, (2) lots of deep sea canyons located north of the amphitheatre, (3) $15-20 \mathrm{~km}$ wide fore-arc basin, (4) $15-20 \mathrm{~km}$ wide flat plane in the axial area of the trench, (5) E-W trending half grabens located on the fore-arc area, etc., which were revealed by several recent topographic survey expeditions.
\end{abstract}

The diving survey by SHINKAI6500 in the fore-arc area on a spur located $120 \mathrm{~km}$ south of Ishigaki Island was carried out in 1992. The site is characterised dominantly by rough topography consisting of a series of steep slopes and escarpments. A part of the surface is eroded due to the weight of the sediment itself and consequently the basement layer is exposed. The site was covered with suspended particles during the diving, due to the present surface sliding and erosion. The same site was re-surveyed in 1997 by ROV KAIKO, which confirmed the continuous slope failure taking place in the site. Another example that was observed by KAIKO expedition in 1997 is a large-scale mud block on the southward dipping slope $80 \mathrm{~km}$ south of Ishigaki Island. This is apparently derived from the shallower part of the steep slope on the southern edge of the fan deposit south of Ishigaki Island.

The topographic features suggest N-S or NE-SW tensional stress over the whole study area. In this sense, the relative motion between the two plates in this area is oblique to the plate boundary. So, the seaward migration of the plate boundary may occur due to the gravitational instability at the boundary of the two different lithospheric structures. This is evidenced by a lack of accretionary sediment on the fore-arc and the mechanism of a recent earthquake which occurred on

Correspondence to: T. Matsumoto (takeshi@jamstec.go.jp)
3 May 1998 in the Philippine Sea Plate 250 km SSE of Ishigaki Island.

\section{Introduction}

Ryukyu Islands are facing the East China Sea to the north and the Ryukyu (Nanseishoto) Trench and the Philippine Sea to the south (Fig. 1). In this arc-trench system area, particularly in the southwestern Ryukyu area, Miyako Islands (mainland $=$ Miyako Island) and Yaeyama Islands (mainland = Ishigaki Island), a number of quite active geological phenomena such as 1771 Yaeyama Earthquake Tsunami, swarm earthquakes since 1990, submarine hot spring spa off Taketomi Island etc. have occurred so far. These phenomena are derived from deformations of the shallow crust due to the subduction of the Philippine Sea Plate underneath the Ryukyu Trench.

The most remarkable of these phenomena is the 1771 Yaeyama Earthquake Tsunami (Great Meiwa Tsunami) which occurred on 24 April 1771 in the lunar calendar. Maximum inundation height of the sea water due to the tsunami is described as $85 \mathrm{~m}$ in the historical record named "Disaster Report of the Large Tsunami" which was presented just after the disaster from the prefectural government of Yaeyama to the Dynasty of Ryukyus. Over 12000 people were killed by the tsunami in Yaeyama and Miyako areas. Quite a lot of evidence, such as stones and rocks thrown up on the shore by the sea water of the tsunami, still remains in these areas (Kato, 1987). The tsunami is considered to have occurred due to a large-scale underwater landslide, and not directly by the earthquake fault. According to the results of a numerical simulation, the height of inundation at the villages in Miyako and Yaeyama areas is not consistent with the result of the calculation of the tsunami propagation by the assumption of a 


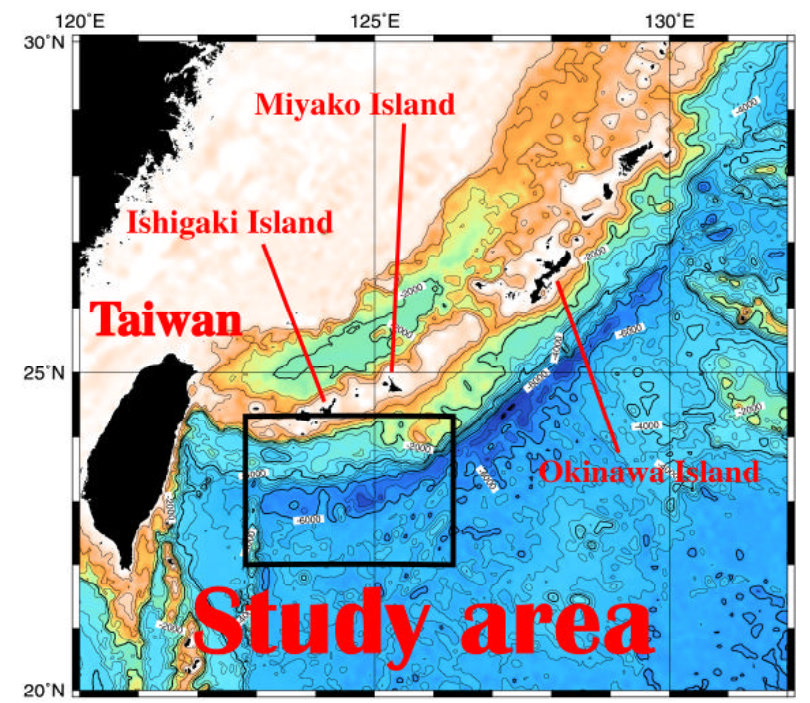

Fig. 1. Index map of the study area in the southwestern Ryukyu arc-trench system.

fault slip induced by an earthquake, but is consistent with that of a large-scale underwater landslide (Hiyoshi, 1986).

In the previous sedimentological work, a core sample including a turbidite in the uppermost layer was obtained at the point of $2193 \mathrm{~m}$ in water depth, and also a core without the sedimentary layer corresponding to the recent 150000 years was obtained at the point of $3136 \mathrm{~m}$ in water depth to the south off the coast of Yaeyama Islands (Ono et al., 1989). The sample with a turbidite on the top suggests the possibility of a transportation of sediment from the shallower water towards the trench area due to a turbidity current induced by an earthquake and/or an underwater landslide. Carbonate should also be supplied to the deep sea area by these mechanisms. The sample which lacks the recent sedimentary layer might be derived from the erosion by a chaotic deep sea current or collapse of the sedimentary layer itself. These problems should be solved by in situ observation and core sampling by use of a deep sea research submersible. Quite a few systematic geological and geophysical survey works were conducted so far in this area, although such kind of phenomena which occurred in the past and may occur at any time in the near future are quite hazardous and are to be studied for the purpose of disaster prevention. Therefore, the joint JAMSTEC-University of the Ryukyus team started geological and geophysical studies in this area by use of the JAMSTEC fleets.

This article is to report the results from the topographic survey in this area and diving by the deep sea research submersible SHINKAI6500 and the deep sea remotely operated vehicle KAIKO and their implications to the mechanism of large-scale tsunamis and tectonics.

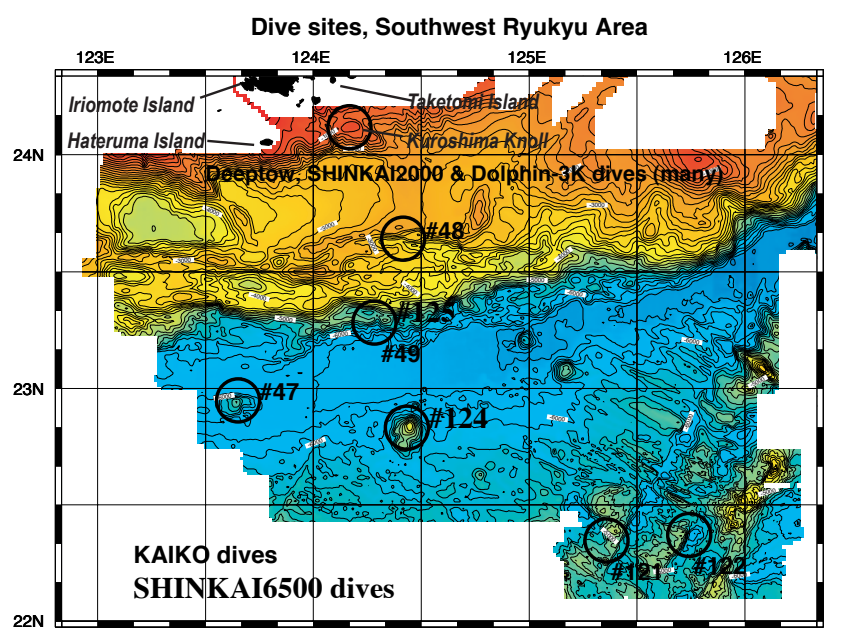

Fig. 2. Topographic map of the study area as observed by the multibeam bathymetric survey system with the dive sites in the southwestern Ryukyu trench - fore-arc area.

\section{Topographic survey}

The present study area is shown in the reference map of Fig. 1. The area north of $24^{\circ} \mathrm{N}$ had already been surveyed (Oshima et al., 1988), and a precise topographic map was published from the Hydrographic Department of Japan. So at first several research cruises by R/V Kaiyo and Yokosuka were devoted to complete a precise topographic map south of $24^{\circ} \mathrm{N}$ off Miyako and Yaeyama area. The first expedition was conducted in November 1990 by DK90-8 Cruise (Kaiyo) Leg 1. The second was in April 1991 by DK91-2 Cruise (Kaiyo) Leg 3. The survey area of these cruises was limited to the assumed epicentral area of the 1771 Yaeyama Earthquake Tsunami. The true origin of the tsunami and the other hazardous phenomena in the southwestern part of the Ryukyu Islands, however, should be derived from the subduction of the Philippine Sea Plate underneath the Nanseishoto (Ryukyu) Trench. So, later in 1992 research cruises by Yokosuka (DY92-1 "Kariyushi" Cruise, January 1992) and Kaiyo (DK92-3 "Tsunamiko" Cruise, April 1992) were conducted in the trench area off Miyako and Yaeyama District, east of Formosa. During the diving cruises by Shinkai6500 (Y92-2 Cruise, June 1992) and KAIREI cruises (KR97-06 Cruise August-September 1997 and KR99-07 Cruise, July-August 1999), supplemental surveys were also conducted in the nighttime and maintenance days. Thus, the area north of $22^{\circ} 05^{\prime} \mathrm{N}$, south of $24^{\circ} 20^{\prime} \mathrm{N}$, east of $122^{\circ} 50^{\prime} \mathrm{E}$ and west of $126^{\circ} 20^{\prime} \mathrm{E}$ was covered by swath bathymetry and a precise topographic map was completed (Matsumoto and Kimura, 1993; Matsumoto et al., 2000; Fig. 2). The multibeam echo sounding systems used for the study were: SEABEAM Classic (on board KAIYO), HS-10 (on board YOKOSUKA) and SEABEAM 2112 (on board KAIREI) systems. These survey cruises revealed some 


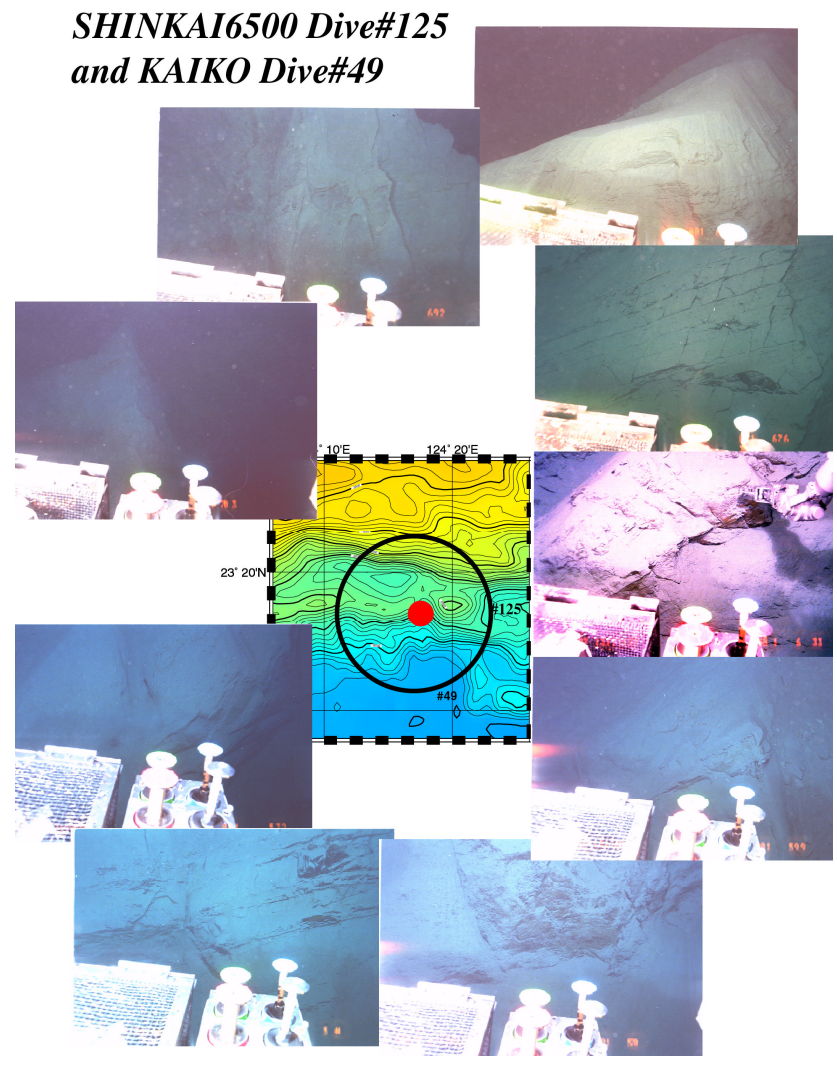

Fig. 3. Some results from SHINKAI6500 Dive\#125 and KAIKO Dive\#49 at the foot of the trench slope on the fore-arc side.

characteristics of the topographic features in the study area. The survey area is classified into five different topographic domains which are arranged zonally. Those are:

Zone-1: North of $24^{\circ} 00^{\prime} \mathrm{N}$, which is characterised by the distribution of well developed submarine canyons along the southern coasts of Yaeyama Islands.

Zone-2: $23^{\circ} 40^{\prime} \mathrm{N}-24^{\circ} 00^{\prime} \mathrm{N}$, which is characterised by slump sediment blocks and their large-scale subsidence edged by steep scarp near $23^{\circ} 55^{\prime} \mathrm{N}-24^{\circ} 00^{\prime} \mathrm{N}, 124^{\circ} 10^{\prime} \mathrm{E}-$ $124^{\circ} 20^{\prime} \mathrm{E}$. The observed relative height of the depression is about $200-300 \mathrm{~m}$.

Zone-3: South of $23^{\circ} 40^{\prime} \mathrm{N}$ on the landward slope of the trench, which is characterised by quite complicated topography, such as several escarpments, ridges and troughs, whose trend is not clearly recognized. An E-W trending half graben is also located here.

Zone-4: Trench axis area with depth of about 6500 $6600 \mathrm{~m}$, which is characterised by broad plain. Maximum width of the axial plain is about $40 \mathrm{~km}$.

Zone-5: Seaward slope of the trench, which is characterised by horsts and grabens, as well as in the sea area south of Okinawa Islands. The strike of the horsts and grabens (rift directions) is NW-SE off Okinawa Islands, and slightly changes to WNW-ESE towards the west.

\section{Diving cruises}

\subsection{Outline}

The area from the Ryukyu fore-arc basin up to the trench axis was first surveyed by SHINKAI6500 in 1992 just after the regional topographic survey. Two dives (Dive\#124 on a seamount on the trench axis, Dive\#125 on the trench slope on the fore-arc side) were then completed (Y92-2 Cruise). After that, three dives by ROV KAIKO (Dive\#47 on another seamount on the trench axis, Dive\#48 and Dive\#49 on the trench slope on the fore-arc side) were conducted in 1997 (KR97-06 Cruise). Kuroshima Knoll, the southern edge of which is considered to be the source area of the 1771 tsunami, was surveyed by JAMSTEC-Deeptow camera system in 1996 (Matsumoto et al., 1997). After Calyptogena colonies were also discovered on the summit of the knoll in 1996, diving survey expeditions were conducted on the knoll by use of ROV Dolphin-3K and Submersible SHINKAI2000 in 1997, 1999, 2000 and 2001 (Matsumoto et al., 1999; Machiyama et al., 2000; Machiyama et al., 2001a, Machiyama et al., 2001b). Figure 2 also shows these dive sites in the study area.

\subsection{SHINKAI6500-Dive\#125: Trench slope (19 June 1992)}

Diving site for the precise observation on the landward side of the trench was selected at $23^{\circ} 15^{\prime} \mathrm{N} 124^{\circ} 15^{\prime} \mathrm{E}$ and nearby (Fig. 3, Fig. 4). The average water depth is $5900 \mathrm{~m}$ during the dive. The site is on a small spur which is sticking out to the south from the landward slope of the trench and is facing the plain bottom surface of the trench area. The spur is bordered by canyons along which the relics of southward underwater landslides are recognised according to the topographic map obtained by HS-10 sounding on board Yokosuka (Matsumoto and Kimura, 1993, Matsumoto et al., 2000; see Fig. 4 in detail).

The diving survey revealed that the whole survey area is characterised dominantly by rough topography consisting of a series of steep slopes and escarpments. The actual topographic roughness scale is much shorter than expected from the topographic map which is obtained by HS-10 multibeam echo sounder with a precision of the beam width at about $250 \mathrm{~m}$ in the case of this water depth. Steep escarpments, some of which are overhung cliffs, might be formed by the self-collapse or underwater landslide rather than fault motion. Ridges and valleys are well developed along the cliff. In some places, a ridge is bordered by a steep slope and steep escarpment, and in other places a steep slope turns abruptly to a steep escarpment. Basement rocks, presumably consisting of sedimentary layer of Shimajiri Formation, are exposed here and there due to the linear sliding of the surface sediment on the slope. Laminar structure was also found on some surfaces of the basement rocks. On a steep slope, several sedimentary layers are piling up like a snowslide, and a part of the surface is eroded due to the weight of the sedi- 


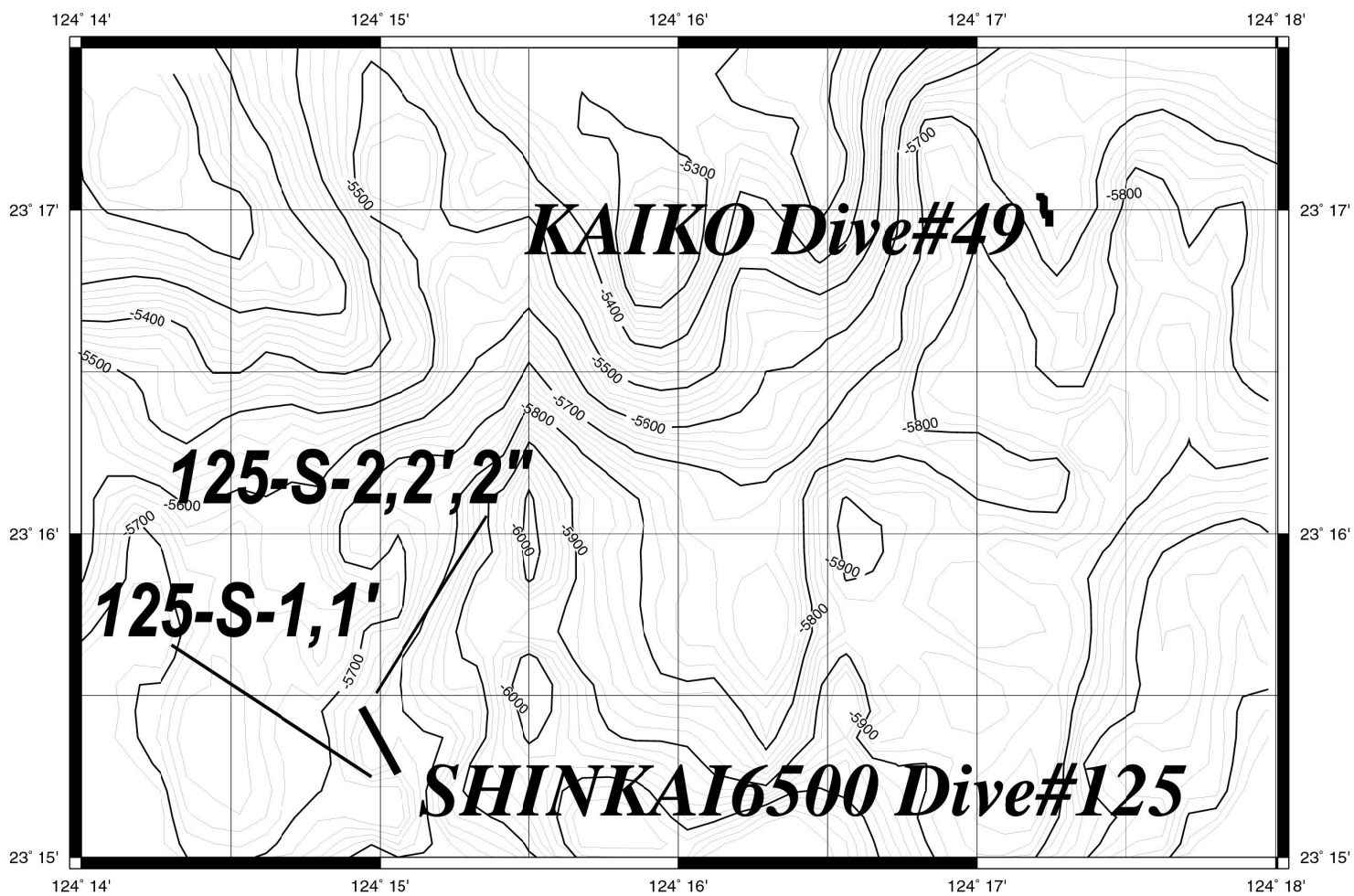

Fig. 4. Precise bottom topography and the submersible/ROV tracks in SHINKAI6500 Dive\#125 and KAIKO Dive\#49.

ment itself and consequently the basement layer, presumably Shimajiri Formation, is exposed. Several layers formed by slided sediment are observed on the flank of the cliff, too.

The surface of the sea bottom was covered with thin soft sediment underlain by a mixture of semi-consolidated clay and fine sand derived from the erosion of the basement layer. The fine sand includes white quartz grains and fine black sand grains. The layer just beneath the surface soft sediment is firm along the whole diving track. Sliding down is more dominant than deposition judging from the fact that the surface muddy layer is too thin to bury the bottom of the valley.

The site was covered with suspended particles during the diving. According to the record of the nephelometer on board the submersible, the minimum was at the water depth of 2000-4000 m, and so these suspended particles were not considered to be from the upper layers. Thus, the dominance of suspended particles should be due to the present sliding and erosion of the surface layer.

As a result, this area is characterised by continuous landslide of the surface of the basement constructed by Shimajiri Formation.

\subsection{KAIKO-Dive\#49 Trench slope (7 September 1997)}

The same site as SHINKAI6500-Dive\#125 was surveyed in order to make sure that the similar collapse and erosion along the slope, an exposure of the basement layer and large number of suspended particles were still taking place. The result was quite the same as that from the previous dive. Push core sampling was tried during the dive but it failed because the seafloor surface was too solid to be penetrated by the push core. It is concluded that such kind of phenomena are always taking place on the trench slope on the fore-arc side due to mass wasting.

\subsection{KAIKO-Dive\#48 Trench slope (5 September 1997)}

The dive was to survey the steep southward dipping escarpment located $80 \mathrm{~km}$ south of Ishigaki Island (Fig. 5). The escarpment seems to be constructed due to an abrupt collapse of the southern end of the fan deposit. The whole track is characterised by thick sediment with bioturbation on it and without any episode of surface deformations. However, at the final site of the dive, it was characterised by a large amount of mud block, apparently dropped from above the northern side of the escarpment. The discovery of the mud block suggests that such a drop may occur in many places around the site on the fore-arc area.

\subsection{SHINKAI6500-Dive\#124: Shiraho Seamount on the trench (17 June 1992)}

There are four seamounts on the trench axial plain area and on the seaward slope of the trench between $123^{\circ} 30^{\prime} \mathrm{E}$ and $125^{\circ} 15^{\prime} \mathrm{E}$. The dive was devoted to the precise survey near the summit of "Shiraho Seamount", the largest one in the area. The summit of the seamount is located at $22^{\circ} 50^{\prime} \mathrm{N}$ $124^{\circ} 27^{\prime} \mathrm{E}, 10 \mathrm{~km}$ south of the plain bottom surface of the trench area. The diameter is about $10 \mathrm{~km}$ in NNE-SSE di- 


\section{KAIKO Dive\#48}

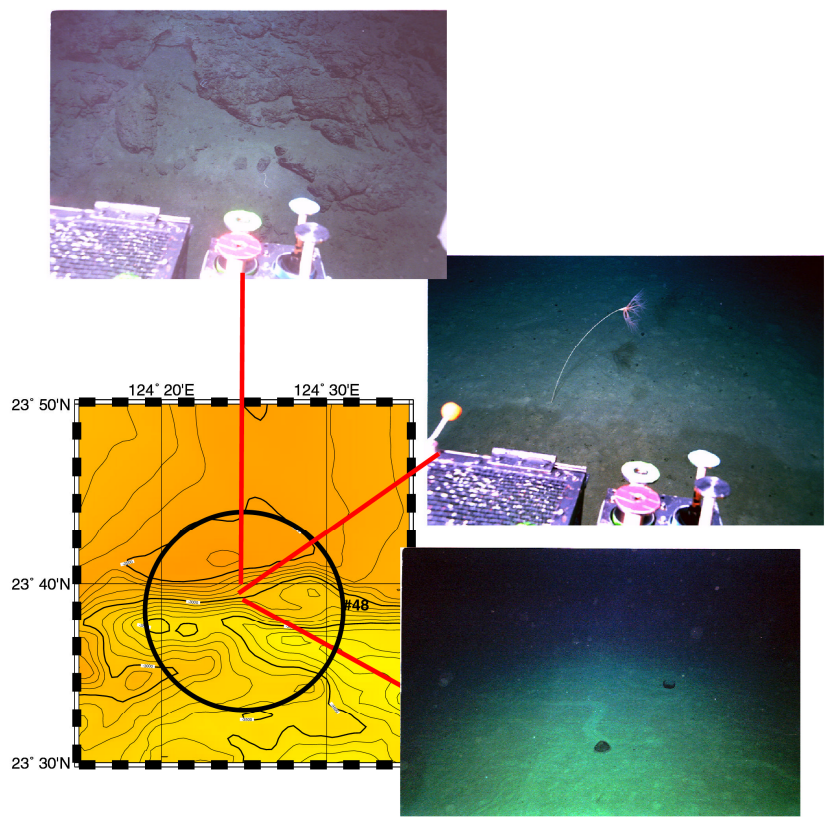

Fig. 5. Some results from KAIKO Dive\#48 at the foot of the fan deposit escarpment on the fore-arc side.

rection and about $8 \mathrm{~km}$ in WNW-ESE direction. The relative height is about $1800 \mathrm{~m}$. The southern part of the seamount seems to be split by an E-W trending fault (Fig. 2).

The dive started at $22^{\circ} 50.033^{\prime} \mathrm{N} 124^{\circ} 27.675^{\prime} \mathrm{E}, 4462 \mathrm{~m}$ in water depth. Plenty of manganese nodules, the diameter of which is a few centimeters, were observed at the site near the point. Ninety of them were collected during the dive. Then the submersible climbed the slope towards the summit to the west. A collapse of the bottom, the diameter of which is about $10 \mathrm{~m}$, was observed at the midst of the seamount slope, $4449 \mathrm{~m}$ in water depth. At $4427 \mathrm{~m}$ and $4422 \mathrm{~m}$ in water depth, a rock similar to a flat board and covered with mud was observed. These rocks seemed to be outcrops. Sparsely distributed fine-medium size pebbles were observed on the slope covered with mud, $4420-4170 \mathrm{~m}$ in water depth. All of them are rocks on the sediment, presumably derived from sliding from the upper part of the seamount. Outcrops covered with thin sediment were observed on the steep slope near the summit, $4163 \mathrm{~m}$ in water depth. These findings suggest that the seamount suffered from deformation recently, maybe at the time when it reached the trench area by the movement of the Philippine Sea Plate.

3.6 KAIKO-Dive\#47 Minami-Hateruma Seamount on the trench (3 September 1997)

The dive was to survey the surface of the Minami-Hateruma Seamount located at $22^{\circ} 57^{\prime} \mathrm{N} 123^{\circ} 38^{\prime} \mathrm{E}$ (Fig. 6). The dive started from the northern slope of the seamount at the water depth of $5270 \mathrm{~m}$. The first landing site was characterised by

\section{KAIKO Dive\#47}
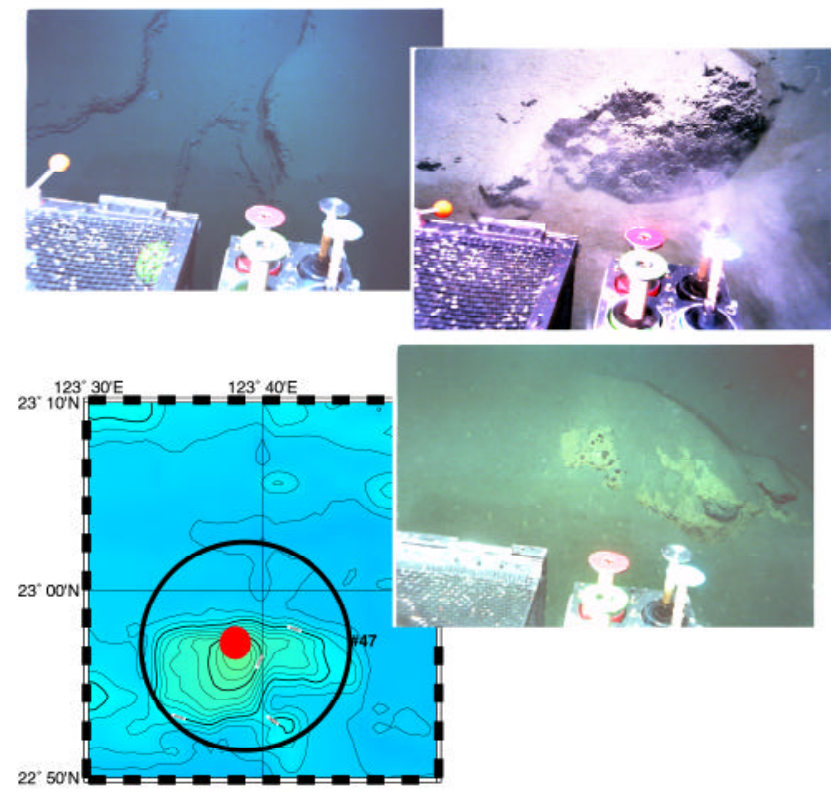

Fig. 6. Some results from KAIKO Dive\#47 around the summit of the Minami-Hateruma Seamount located on the trench axis.

Table 1. Sand content in the sediment samples obtained by the SHINKAI6500 Dive\#124 and Dive\#125

\begin{tabular}{cccc}
\hline Sample name & Sand content $(\%)$ & Depth $(\mathrm{m})$ & Sampler \\
\hline \#124 1-S1 & 2,88 & 4.462 & grab \\
$\# 125 \mathrm{~S}-1$ & 39,60 & 5.707 & core \\
$\# 125 \mathrm{~S}-1^{\prime}$ & 40,83 & 5.707 & grab \\
$\# 125 \mathrm{~S}-2$ & 1,85 & 5.661 & grab \\
$\# 125 \mathrm{~S}-2^{\prime}$ & 7,55 & 5.661 & grab \\
$\# 125 \mathrm{~S}-2^{\prime \prime}$ & 2,78 & 5.661 & grab \\
\hline
\end{tabular}

a collapse of the soft sediment towards the lower part of the slope. Basement rocks were episodically observed towards the summit and the collected rock samples were covered with manganese crust, which suggests sedimentation on a largescale collapse in the older age. The surface is similar to that of the Shiraho Seamount $75 \mathrm{~km}$ east of the site.

\section{Description of the sediment}

The analysis of the sediment samples collected by $6 \mathrm{~K} \# 124$ and \#125 was carried out. Table 1 shows the sand content in the layer from the surface to $10 \mathrm{~cm}$ in thickness. One sample was collected by Dive\#124 and two by Dive\#125. The first observation is that the sand content of the samples collected from the landward side of the trench is extraordinarily high, about $40 \%$ in \#125-S-1 and \#125-S-1' ${ }^{\prime}$. The content of sand decreases as the water depth increases in the present 
Table 2. Sand content in the piston core samples obtained by the Nagasaki-Maru cruise in 1987 (Ono et al., 1989). The stations are located south of Yaeyama Islands and north of the SHINKAI6500 Dive\#125 site

\begin{tabular}{ccc}
\hline Sample name & Sand content $(\%)$ & Water depth $(\mathrm{m})$ \\
\hline RN87PC1 & 40,00 & 1.074 \\
RN87PC3 & 14,38 & 1.665 \\
RN87PC4 & 15,50 & 2.488 \\
RN87PC5 & 7,80 & 3.136 \\
\hline
\end{tabular}

study. However, as compared with the result of the analysis of core sampling obtained by R/V Nagasaki-Maru near the coast of the Yaeyama Islands (Ono et al., 1989; Table 2), the present survey area has a higher content of sand although the content of sand decreases as the water depth increases as for the present samples. However, "\#125-S-2, S-2' .S-2" present lower values compared with those above; the sand content in this area has considerable fluctuations depending on the sampling sites. This might be due to the erosion of the muddy sediment on the surface and exposure of the internal sandy sediment in some sampling sites.

Table 3 shows the result of analysis of chemical compositions. Sample \#124-1-S1 includes minerals such as quartz and volcanic glass, and does not include carbonate. Samples collected by Dive\#125 consist of over $70 \%$ quartz and 17$18 \%$ mica, and also contain carbonate which is not included in the sample by Dive\#124. It is not clear if the carbonate particles are derived from organisms. There are two possibilities: these are transported from the area near the coast, or these are due to the erosion of the in situ basement rocks. Sample \#125-S-2' includes a small amount of Amphistegina fragments. These fragments collected at $5600 \mathrm{~m}$ in water depth are almost dissolved and much thinner than the ordinary samples, which is consistent with the water depth of the sampling point considering that the calcium carbonate compensation depth in the Pacific area is $4200-4500 \mathrm{~m}$. In the same sample a deformed planktonic foraminifera was found which is usually included in Shimajiri Formation. This is obviously derived from the eroded basement rocks. However, no remarkable evidence to specify the basement as Shimajiri Formation was observed from the analysis of particles, although the bedding observed on the exposed basement in Dive\#125 is almost horizontal, which is quite similar to that observed in the land area of the Ryukyu Islands.

\section{The 3 May 1998 Off Yaeyama Earthquake}

On 3 May 1998 (UTC) an earthquake (M7.7 by Japan Meteorological Agency, $M s 7.3$ by Earthquake Research Institute, University of Tokyo) occurred about $250 \mathrm{~km}$ south of Ishigaki Island. The estimated epicentre was $22.4^{\circ} \mathrm{N} 125.6^{\circ} \mathrm{E}$, $20 \mathrm{~km}$ deep. The CMT focal mechanism reported by Harvard University was almost a left-lateral strike-slip with the strike of $\mathrm{N} 45^{\circ} \mathrm{W}$ which corresponds to the distribution of the after-

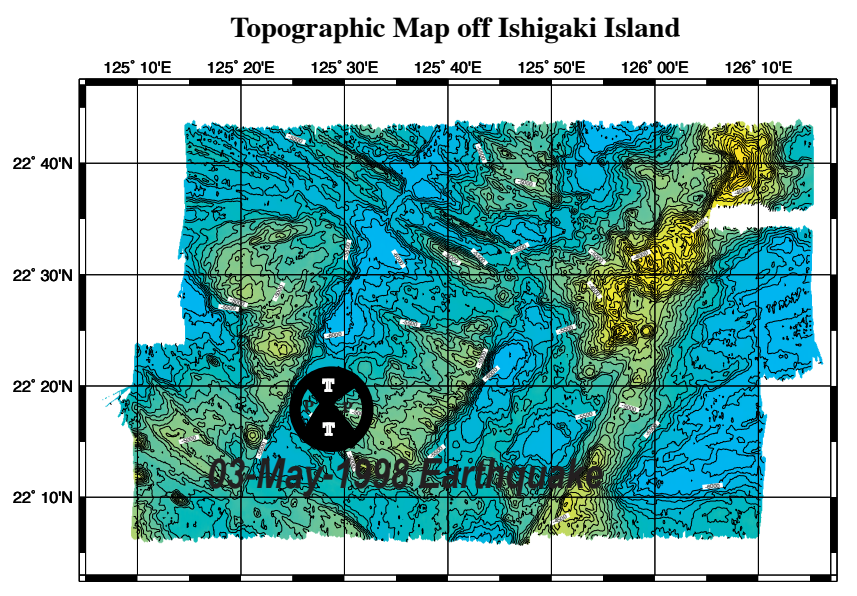

Fig. 7. Topographic map of the area around the epicentre of 3 May 1998 Off-Ishigaki Earthquake with its Centroid Moment Tensor solution by Harvard University.

shocks by Japan Meteorological Agency. This is apparently an intra-plate earthquake which took place just adjacent to the convergent plate boundary (Ryukyu Trench).

Figure 7 shows a close-up of the topographic map of the epicentral area of the earthquake with the CMT focal mechanism. The area is characterised by three major topographic lineaments. They are:

1. WNW-ESE: based on the horst and graben which continues from the seaward side of the Ryukyu Trench area off Okinawa Island. The strike changes gradually from NW-SE to WNW-ESE towards west. This is corresponding to the early stage of the opening of the Philippine Sea.

2. NNE-SSW: based on the fracture zones running across the horst and graben. The interval of the lineaments is almost constant and is about $15 \mathrm{~km}$.

3. $\mathrm{N} 45^{\circ} \mathrm{W}$ : The strike of the topography corresponds to that of the focal mechanism of the 3 May 1998 earthquake. KAIKO dives after the topographic survey revealed that this lineament was most recent in that surface deformation without sediment cover or manganese crust was observed.

The focal mechanism and the topographic lineament suggests that the area south of the trench is characterised by E-W compressional and/or N-S tensile stress field.

\section{Discussion}

As mentioned above, the topographic features in the present study area are: $15-20 \mathrm{~km}$-wide, E-W trending flat plane of the axial area of the trench, E-W trending half graben placed on the landward slope, gradual change of the trend of the horst and graben towards the west. These topographic features suggest N-S tensional stress (and also E-W compres- 
Table 3. Content of minerals and microfossils in the sediment samples obtained by the SHINKAI6500 Dive\#124 and Dive\#125

\begin{tabular}{ccccccccc}
\hline Sample name & Quartz & Mica & Other min. & Carbonate & Vol. gla. & Radio. & Spo. Spic. (\%) & Total \\
\hline \#124 1-S1 & 40,55 & 1,15 & 25,58 & 0,00 & 26,72 & 3,23 & 2,76 & 100,00 \\
$\# 125$ S-1 & 72,71 & 16,94 & 0,00 & 10,35 & 0,00 & 0,00 & 0,00 & 100,00 \\
$\# 125$ S-2 & 78,95 & 18,18 & 0,00 & 2,87 & 0,00 & 0,00 & 0,00 & 100,00 \\
$\# 125$ S-2 & 74,71 & 17,43 & 0,00 & 7,66 & 0,00 & 0,00 & 0,19 & 100,00
\end{tabular}

Other min. = Other minerals; Vol. gla. = Volcanic glasses; Radio. = Radioralia; Spo. Pic. = Sponge Spicules

Particles over 149 micrometers in diameter only.

sion as is shown in the CMT solution of 3 May 1998 earthquake) over the whole study area. Considering that the western part of the East China Sea north off Miyako and Yaeyama Islands is characterised by a broad basin and that the water depth is more than $2000 \mathrm{~m}$ in contrast with the northeastern part, the whole southwestern Ryukyu area is characterised by the features derived from such kind of tensional stress. It is well known that an accretion of pelagic sediment from the seaward side of the trench is dominated at the trenches around Japan Island Arc. However, this is due to the active plate convergence in the trench area. Some results of the numerical simulation show that the trench axis shifts to the seaward side due to the negative buoyancy of the subducting lithosphere underneath the asthenosphere and that the tensional stress perpendicular to the trench axis arises at the landward side if no active plate convergence is taking place and two different plate blocks with different lithospheric structures are making a contact (Matsumoto and Tomoda, 1986). In this sense, the relative motion between the Philippine Sea Plate and Eurasia Plate in the southwestern part of the Ryukyu arc-trench system is not actively convergent and the component parallel to the plate boundary is predominant regarding the general plate motions. So, the seaward shift of the plate boundary may occur due to the gravitational instability at the boundary of the two different lithospheric structures. This is evidenced by the exposure of the basement layer (SHINKAI6500 Dive\#125, KAIKO DIVE\#49) and a lack of accretionary sediment which was observed on the landward slope of the trench.

Since no historical record of tremor was identified that corresponds to the Great Meiwa Tsunami, it might be reasonable to consider a large-scale underwater landslide or collapse of sediment as the origin of the tsunami. In the coastal area off Miyako and Yaeyama Islands, a number of underwater canyons are located and most of them are connecting these islands and the Nanao Basin, the northernmost part of which coincides with the large-scale depression and the estimated origin point of the generation of the tsunami. As soft sediment is always supplied from these islands through the underwater canyons, an underwater landslide might occur along a steep slope on the island shelf if the sediment accumulates on the slope and the slope becomes unstable due to a high gradient of the seafloor. This is evidenced by a repeated turbidite layer observed in the core samples off the islands (Ono et al., 1989), or for some conditions a collapse is just now

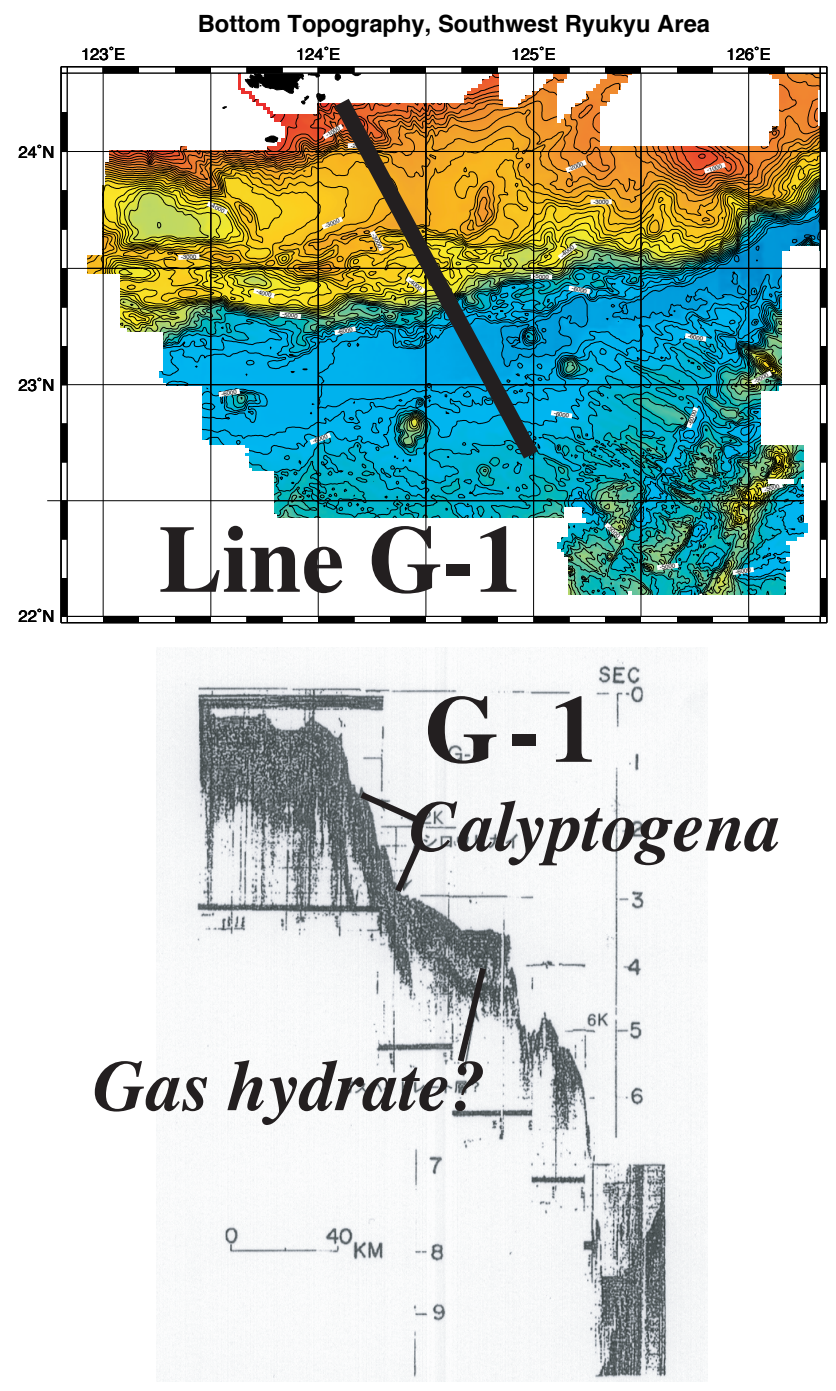

Fig. 8. Record of single-channel seismic profile crossing the study area from Geological Survey of Japan (Kimura et al., 1980). High intensity reflector underneath the mid slope $(3.0 \sim 4.5 \mathrm{~s}$ TWTT $)$ suggests the upper surface of gas hydrate layer.

taking place in the present study area on the landward slope.

One more possible cause of occurrence of landslides is a potential gas hydrate underneath the Ryukyu fore-arc. The distribution and pattern of the chemosynthetic communities (clams and tube worms) were surveyed and the relationship 
between the distribution and surface structure was observed through the diving expeditions on the Kuroshima Knoll on the fore-arc slope (Matsumoto et al., 1999; Machiyama et al., 2000; Machiyama et al., 2001a). Active gas bubble eruption sites and large Bathymodiolus colonies that were discovered recently on the Kuroshima Knoll (Machiyama et al., 2001b) suggest definitely the existence of a gas hydrate layer underneath the fore-arc region. The area corresponding to the communities is also characterised by recently formed surface ruptures, brecciated rocks, sedimentary mounds and cylindrical calcareous sandstone chimneys. It should be estimated that crustal movement associated with basement fracturing and its subsequent cold water seepage were taking place repeatedly in the past. At these times, a gas eruption through calcareous sandstone layers might have occurred and constructed "cold" chimneys due to a high pressure of gas content in the sedimentary layer. Figure 8 shows the record of single-channel seismic profile crossing the study area (Kimura et al., 1980). The boundary beneath the transparent layer corresponds to the basement. The upper boundary on the transparent layer may correspond to the BSR, suggesting a gas hydrate layer underneath the deeper part of the trench slope of the fore-arc side, although the boundary is not clear at the edge. The depth of the BSR is estimated to be some $3000 \mathrm{~m}$ where methane hydrate is stable considering that the field parameters at the site are plotted below the hydrate-gas boundary curve on the pressure-temperature phase boundary diagram (Field and Kvenvolden, 1985; Kvenvolden and McDonald, 1985). Formation of gas hydrate in the fore-arc area may weaken the materials underneath slope and then an underwater landslide and subsequent large-scale tsunami may occur easily, since similar features are observed in other fore-arc areas (Sweet and Silver, in press; Kopp et al., 2000).

\section{References}

Earthquake Prediction Information Division and Okinawa District Meteorological Observatory, Japan Meteorological Agency: The M7.6 Earthquake on 4 May 1998 and M6.3 Earthquake on 20 November 1998 in the south off Ishigakijima Island, Report of the Coordinating Committee for Earthquake Prediction, 61, 538$541,1999$.

Field, M. E. and Kvenvolden, K. A.: Gas hydrates on the northern California continental margin, Geology, 13, 517-520, 1985.

Hiyoshi, Y., Ando, M., and Kimura, M.: Generation mechanism of the 1771 Nanseishoto Great Meisa Tsunami - generation of a large-scale underwater landslide, Abstract Volume of the Annual Meeting of the Seismological Society of Japan, 80, 1986.

Kato, Y. and Oyama, S.: Yaeyama Seismic Tsunami at Tarama Island, the Ryukyu Islands II. Comparison of traditions with movement of tsunami inferred from coral blocks, Bulletin of the College of Science, University of the Ryukyus, 45, 245-252, 1987.

Kato, Y.: Yaeyama Seismic Tsunami (1771) in the Miyako Islands recorded in the newly-found archives "Otoiai-gaku," Bulletin of the College of Science, University of the Ryukyus, 47, 153-158, 1989.

Kimura, M., Honza, E., and Miyamoto, M.: Submarine geology around the southern Ryukyu Islands, with special reference of the Okinawa Trough, Geological Studies of the Ryukyu Islands, 4, 79-93, 1980.

Kimura, M., Matsumoto, T., Kagami, M., and Mifune, S.: Seismicity and crustal movement of Ryukyu Arc, Proceedings of International Workshop on Scientific Use of Submarine Cables, 75, 1997.

Kopp, H., Flueh, E. R., Klaeschen, D., Bialas, J, Reichert, C., and GINCO Working Group: Crustal structure along the central Sunda Arc, EOS, Transactions (Supplement), 81, 48, F1128, 2000.

Kvenvolden, K. A. and McDonald, T. J.: Gas hydrates of the Middle America Trench, Deep Sea Drilling Project Leg84, in von Huene, R., 667-682, 1985.

Machiyama, H., Hattori, M., and Matsumoto, T.: Calcareous chimneys from the Kuroshima Knoll, south of Yaeyama Islands, Japan, EOS, Transactions (Supplement), 81, 22, WP64, 2000.

Machiyama, H., Shinjo, R., Hattori, M., Okano, M., Matsumoto, T., Kimura, M., Nakamura M., Toyama, G., and Okada, T.: Outline of Dolphin-3K dive surveys on the Kuroshima Knoll in the southern Okinawa Trough - preliminary report of the NT00-05 Cruise, JAMSTEC Journal of Deep Sea Research, 18, 15-30, 2001 a.

Machiyama, H., Matsumoto, T., Matsumoto, R., Hattori, M., Okano, M., Iwase, R., and Tomaru, H.: Outline of Shinkai2000 dive surveys on the Kuroshima Knoll off Ishigaki Island - Preliminary report of the NT01-05 Leg1 Cruise, JAMSTEC Journal of Deep Sea Research, 19, 45-60, 2001 b.

Matsumoto, T. and Tomoda, Y.: Numerical simulation of the process of the crustal and lithospheric movements, Roy. Soc. NZ. Bull., 24, 493-505, 1986.

Matsumoto, T. and Kimura, M.: Detailed bathymetric survey in the sea region of the estimated source area of the 1771 Yaeyama Earthquake Tsunami and consideration of the mechanism of its occurrence, Journal of the Seismological Society of Japan, Second Series, 45, 417-426, 1993.

Matsumoto, T., Kimura, M., Nishida, S., Nakamura, T., and Ono, T.: Chemosynthetic communities and surface ruptures discovered on the Kuroshima Knoll south of Yaeyama Islands (NT9714 Cruise), JAMSTEC Journal of Deep Sea Research, 14, 477491, 1999.

Matsumoto, T., Kimura, M., and Nakamura, M.: Chemosynthetic communities and surface ruptures discovered on the western Ryukyu fore-arc area - possible sedimentation processes and formation of gas hydrate, EOS, Transactions (Supplement), 81, 22, WP221, 2000.

Matsumoto, T., Uechi, C., and Kimura, M.: Surface deformation at the origin area of the 1771 Yaeyama Earthquake Tsunami observed by the precise survey off Yaeyama districts, Ryukyu area, JAMSTEC Journal of Deep Sea Research, 13, 535-561, 1997.

Okinawa District Meteorological Observatory, Japan Meteorological Agency: Recent seismic activity in and around the Okinawa district (November 1997 - April 1998), Report of the Coordinating Committee for Earthquake Prediction, 60, 565-568, 1998.

Okinawa District Meteorological Observatory, Japan Meteorological Agency: Recent seismic activity in and around the Okinawa district (May - October, 1998), Report of the Coordinating Committee for Earthquake Prediction, 61, 519-521, 1999.

Ono, T., Midorikawa, Y., Yamamoto, S., and Ujiie H.: Sediments taken from the sea-bottom around the southern Ryukyu Island Arc during the RN-84, -86, and -87 cruises, Bulletin of the College of Science, University of the Ryukyus, 47, 115-151, 1989.

Oshima, S., Takanashi, M., Kato, S., Uchida, M., Okazaki I., Kasuga, S., Kawashiri, C., Kaneko, Y., Ogawa M., Kawai K., Seta, 
H., and Kato, Y.: Geological and geophysical survey in the Okinawa Trough and the adjoining seas of Nansei Syoto, Report of Hydrographic Researches, 24, 19-43, 1988.

Sweet, S. and Silver, E. A.: Seismic reflection images of the source region of the 1998 Papua New Guinea Tsunami, in: "Prediction of underwater slide and slump hazards", (Eds) Watts, P., Synolakis, C. E., and Bardet, J.-P., Balkema, Rotterdam, Netherlands, in press. 